\title{
Mirror Surface Finishing of Brittle Materials by Table-top ELID Lap Grinding Machine
}

\author{
○正 長谷川勇治（茨城高専） 正 大森 整（理化学研究所） \\ 正 伊藤 伸英（茨 城 大）正 伊藤 吾朗（茨 城 大）
}

Yuji HASEGAWA, Ibaraki National College of Technology, Hitachinaka, Ibaraki

Nobuhide ITOH, Ibaraki University, Hitachi, Ibaraki

Goroh ITOH, Ibaraki University, Hitachi, Ibaraki

Hitoshi OHMORI, Institute of Physical and Chemical Research, Wakoh, Saitama

Key words : Mirror Surface Grinding, Brittle Materials, ELID (Electrolytic In-process Dressing) Grinding

\section{1. 緒 言}

我々の情報化社会を支えるハイテク機器が高機能化 -小型化するのに伴い, これらを構成する電子・光学 素子, 機会部品もまた高精度・小型化が求められてき ている。このため，それぞれの機能に合った新しい素 材の研究・開発も活発に行われている。従来これらの 素子・部品の最終仕上げ法として遊離砥粒を用いたラ ッピング・ポリシングが用いられているが，新しく開 発された新素材の中には異方性や難加工性を有してい るものが少なくなく，このためた従来の遊離砥粒によ る加工では対処が困難な場合もでてきている，そこで 我々は，これらの問題を解決し効率的な最終仕上げ法 の構築を目的として ELID 研削法と砥石ラッピングを 組み合わせた ELID ラップ研削法 ${ }^{\prime}$ を提案し，その実 用化を目指して検討を進めている。

今回，本加工技術の実用化の一環として開発した卓 上型 ELID ラップ加工機 ${ }^{2)}$ による脆性材料の基礎的な 加工特性について調查を行なった結果を報告する.

\section{2. 卓上型 $\mathbb{E L I D}$ ラップ研削加工機}

\section{$2.1 \mathbb{E L I D}$ ラップ原理}

本加工機は， Fig.1 に示す ELID ラップ研削原理を基 本として開発を行ったものである。本システムの原理 は, 砥石を電解電源装置の陽極に接続し, 陰極と接続 した電極を砥石表面から僅かな隙間を設けて対向させ る。この僅かな隙間に研削液と電解電流を供給するこ とにより,この間で電解反応を発生させ導電性ボンド 材のみ電解溶出させる.この結果, 電気分解作用に影 響を受けない砥粒が突出し，安定した加工を実現する。

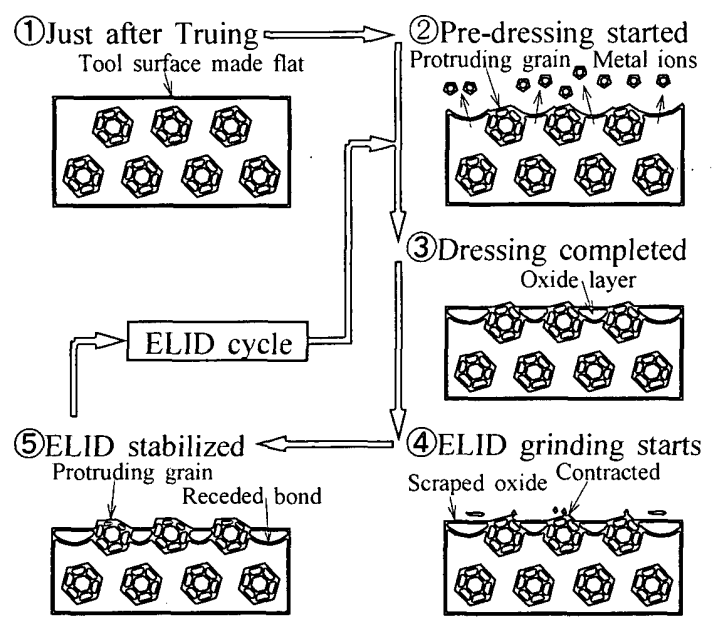

Fig.1 Schematic Illustration of ELID Grinding System

\section{$2.2 \mathbb{E} \mathbb{L I D}$ ラップ研削加工機 "Lap de Top"}

本加工機は，ELID ラップ研削原理を利用し，簡易か つ効果的に各種の硬脆性材料の精密鏡面研削加工を実 現するたに開発した卓上型加工機である．加工は，ワ 一クをエア加圧によって砥石に押しつけて加工を行う。 この方式はバネ加圧式に比べ，ワークの砥石面性状へ の追従性が良く，より高品位な加工面を得ることがで きる。また，エア圧力を変えることにより，ワークの 材質, 寸法に適した負荷を架けることが出来る。Fig.2 に加工機外観を,以下に本加工機の特徽を示す.

1）商用交流 $100 \mathrm{~V}$ で使用可能

2）作業環境がクリーン(砥石を使用するため)

3）小型・軽量化のため容易に移動が可能

4) 粗砥粒砥石から微細砥粒砥石の使用が可能 硬脆材料の粗加工から鏡面加工まで実現

5) 砥石に偏心運動 $(0 \sim 5 \mathrm{~mm})$ をさせることができる 6）ワークに適した固定，ユニバーサル型が選択可能

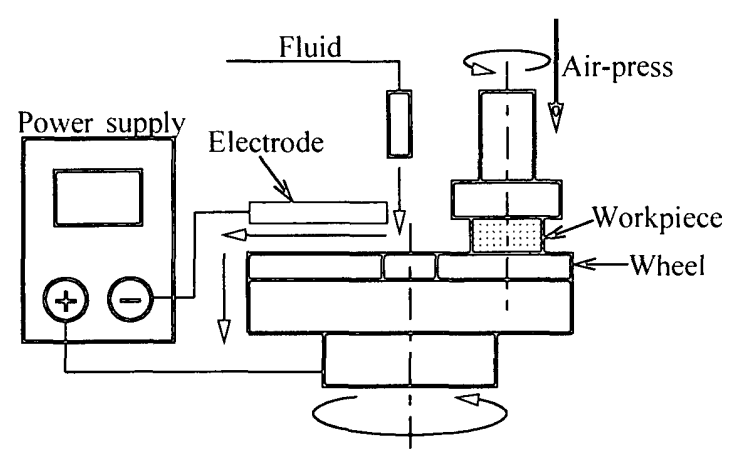

Fig.2 Schematic Illustration of $\mathbb{E L I D}$ Lap Grinding Machine

Table.1 Experimental System and Experimental Condition

\begin{tabular}{|l|l|c|}
\hline Grinding Machine & Table-top ELID Lap Grinding Machine \\
\hline Grinding Wheel & $\begin{array}{l}\text { Metal-Resin Bonded Diamond Wheel } \\
\text { Average diameter: 2000nm } \# 8000) \\
\text { Conc.: 100 Size: } \phi 200 \times \text { W35mm }\end{array}$ \\
\hline Power Supply & FUJI ELIDER ED1505 \\
\hline Grinding Fluid & AFG-M (2\% dilution to water) \\
\hline Workpiece & FCY40A (Ceramics) $\phi 30 \times 5 \mathrm{~mm}$ \\
& SKD61 (Tool steel) $\phi 10 \times 5 \mathrm{~mm}$ \\
\hline Electrolytic & Open voltage & \multicolumn{1}{|c|}{$60 \mathrm{~V}$} \\
Conditions & Peak current & $2 \mu \mathrm{A}$ \\
& Pulse on-off time & $120 \mathrm{rpm}$ \\
& Wheel speed & $120 \mathrm{rpm}$ \\
Grinding & Work speed & $0.1 \mathrm{MPa}$ \\
\hline
\end{tabular}


3. ELID ラップ研削機の加工特性

3.1 実験システム

本実験システムの仕様と加工条件を Table.1に示す. また, Photo.1に研削加工中の様子を示す.

\section{2 初期電解ドレッシング特性}

Fig.3 に初期電解ドレッシング時の実電流值，実電圧 值の挙動を示す。実電流值の挙動は，一般的な ELID 研削と同様にドレッシング時間の経過とともに非線型 に減少し，以後一定值を示す傾向を示した。安定する までに要した時閒は約 30 分であった。また，砥石面も 銅色から茶緑色に変化し, 砥石表面がボンド材の酸化 物で覆われたことが確認できた。

\section{3 実験結果}

使用砥石の電解ドレッシング後, 加工実験を行った。

Fig.4に累積加工量と時間の関係を示す。FCY40A, SKD61 ともに安定した加工が行われているが，加工能 率に差がみられる。これは、材料の硬度の影響により 加工能率に差が生じていると考えられる。

Fig.5に加工後の加工面あらさを示す. FCY40A が 36.0nmRy，SKD61 が 44nmRyという良好な結果を得た。

Photo.1にSKD61 の光学顕微鏡写真, Photo. 2 に FCY40A の加工面状態の写真を示す。加工面に研削痕 が観測されるが，表面状態は平滑な状態となっている ことがわかる。

\section{4. 結言}

ELID ラップ研削法の実用化の一環として開発した卓 上型 ELID ラップ研削機による硬脆材料の加工実験の 結果，長時間加工において安定した加工が行われ，優 れた加工面あらさが得られることが確認された。今後, 材料特性に適した加工条件の検討を行う予定である。

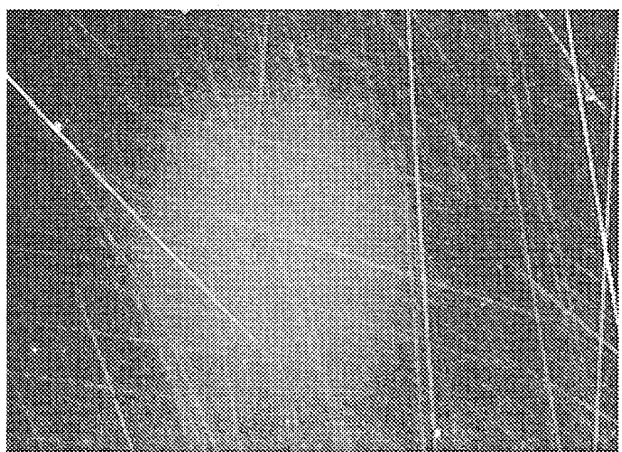

\section{Photo.2 Optical micrograph of finished SKD61}

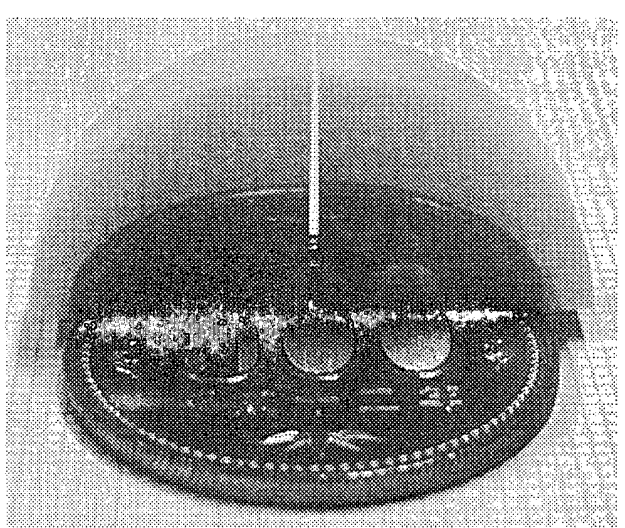

Photo.3 View of finished FCY40A

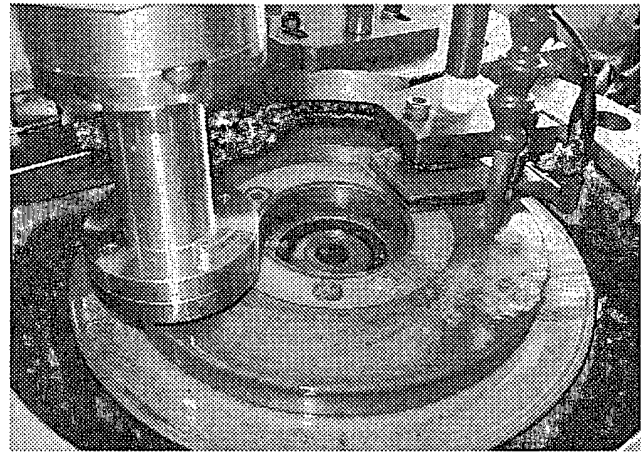

Photo.1 Close-up of ELID lap grinding machine

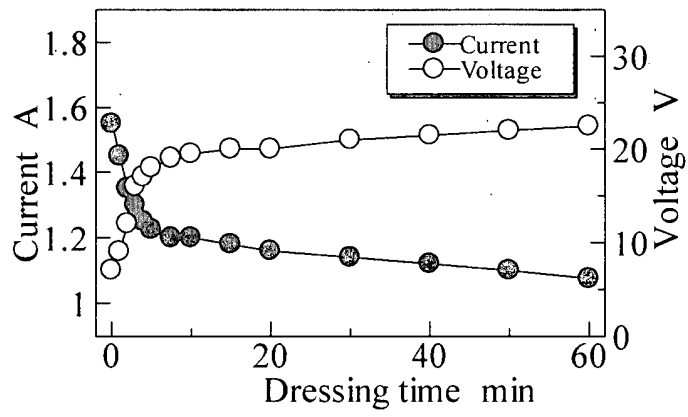

Fig.3 Electrical Behavior of Pre-dressing

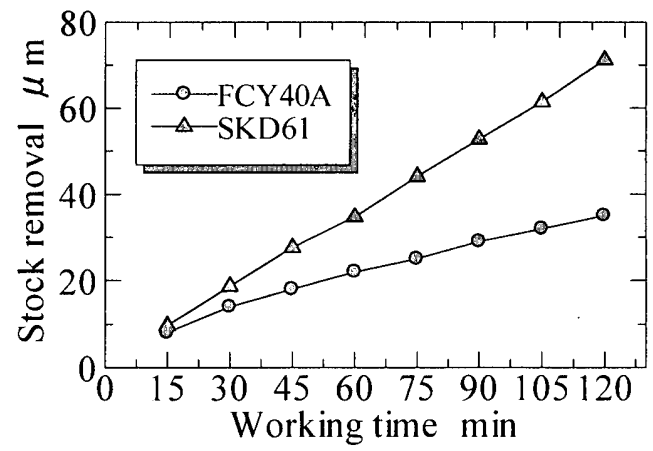

Fig.4 Results of Stock Removal

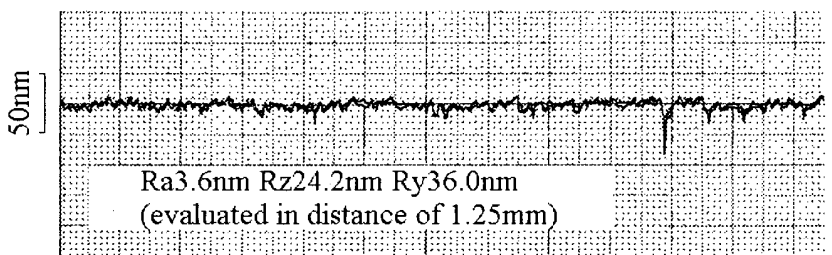

(a) FCY40A

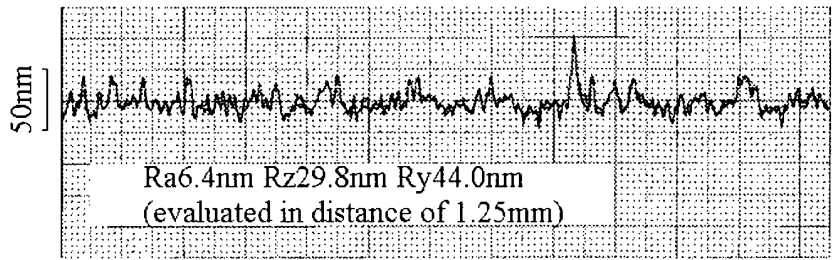

(b) SKD61

Fig.5 Results of Surface Roughness

参考文献

1）大森, 中川；サブミクロン固定砥粒によるラップ研 削，1990年精密工学会春季学術講演会論文集，993

2）伊藤, 大森, 河西,士肥, 上竹, 矢野; ELID ラップ 研削機 "Lap de Top"による硬脆材料の加工特性, 2000 年精密工学会春季学術講演会論文集, G61 